REVIEWS

\title{
Plant biomass increase: recent advances in genetic engineering
}

\author{
L. O. Sakhno \\ Institute of Cell Biology and Genetic Engineering, NAS of Ukraine \\ 148, Akademika Zabolotnogo Str., Kyiv, Ukraine, 03680 \\ sakhno@icbge.org.ua
}

\begin{abstract}
Plant biomass enhancement using transgenesis in model as well as in crop plants both under optimal and stress controlled (greenhouse or growth chamber) and field conditions is observed. It was documented that genetic engineering approaches allow reaching up to two-fold increase of biomass in optimal conditions. Both transgenic and initial plants reduce biomass production under stress. It was demonstrated that it can be up to 2-fold increase in productivity of transgenic plant versus untransformed one in stress. Some heterologous gene expression features influencing plant biomass production are discussed.
\end{abstract}

Keywords: biomass, dry weight, fresh weight, stress, transgenic plants.

Introduction. Plants are photoautotrophic organisms which using light energy can transform inorganic carbon dioxide to carbohydrates and then to other compounds and in this manner form their biomass. We use plants for food and in different fields of our activity such as construction, textile, pharmaceutical and chemical industries. Plant biomass has also been considered as an important renewable source of biofuels [1, 2]. Enhancing plant height, growth rates and total biomass retains a principal demand due to the growing of the world population.

Considerable efforts of the plant scientists have been aimed at the problem of plant biomass increase. Plant growth markedly depends on availability of essential nutrients such as nitrogen and phosphorus which modulate a number of aspects of the plant development including root and shoot branching and enlargement, leaf growth, flowering time, and regulate expression of many genes involved in nitrogen and carbon metabolism $[3,4]$. Genetic engineering investigations on nitrogen assimilation for the improvement of nitrogen efficiency have recently been deeply reviewed $[5,6]$.

(c) Institute of Molecular Biology and Genetics, NAS of Ukraine, 2013
Engineering of photosynthesis in crop species can significantly increase agricultural productivity. Summarizing the results obtained in the model objects on improvement of photosynthetic electron transport chain, rubisco activity and specificity, Rubisco activation state, photorespiration, sedoheptulose-1,7-bisphosphatase/fructose-1,6-bisphosphatase activity, Peterhansel et $a l$. focused their attention on necessity to test elaborated approaches in true crops under conditions of agricultural production [7].

The regulation of carbon allocation between photosynthetic source - leaves and sink tissues - is an important factor controlling plant yield [8]. Plant organs are initiated as primordial outgrowths, and require controlled cell division and differentiation to achieve their final size and shape. Plant hormones thinly regulate plant growth and affect total biomass and yield production [9-12]. Transgenesis allows identification of the mechanisms of complex resistance to stresses and thus leads to an increase in production of plant biomass in non-optimal conditions [13].

The aim of this review was to show the last achievements in genetic engineering and perspectives of some approaches (different promoters, fused genes) for opti- 
mization of ectopic gene expression for crop biomass increase under field.

Biomass increase in optimal growth conditions. Changes in the plant biomass accumulation can be achieved by regulation of the carbohydrate metabolism [14-16]. Simultaneous upregulation of UDP-glucose pyrophosphorylase, sucrose synthase and sucrose phosphate synthase resulted in enhanced primary growth; for example, for tobacco Nicotiana tabacum L. in some cases an increase in height growth was over $50 \%$ [17]. Due to the increased sucrose phosphate synthase activity the total Arabidopsis (Arabidopsis thaliana L.) biomass was 2-fold higher in AtPAP2 (purple acid phosphatase) overexpressed plants than in wild-type [18]. The RNAi-mediated down-regulation of glucan waterdikinase (the primary enzyme required for starch phosphorylation) under the control of an endosperm-specific promoter led to a decrease in starch phosphate content in common wheat (Triticum aestivum L.) [19]. Consistent increase in vegetative biomass, grain size and grain yield was observed in subsequent generations in both greenhouse and field trials. Overexpression of sucrose synthase (SusA1) gene from a superior quality fiber germplasm line 7235 in cotton Gossypium hirsutum increased fiber length and strength [20]. Increasing GhSusAl transcript abundance in vegetative tissues led to elevated seedling biomass.

Many biotechnological systems have been established to advance enhancing plant height, growth rates and total biomass with emphasis on increasing the concentration of the plant hormones or on their signalling. Overexpression of the most studied gibberellin biosynthesis enzyme, GA 20-oxidase gene, resulted in an excessively high activity of gibberellin deactivating enzyme, GA 2-oxidase. It was shown that silencing the gibberellin deactivating enzyme in tobacco plants resulted in a dramatic improvement of their growth characteristics, compared with the wild type and GA 20-oxidase over-expressing plants [21]. Suppression of PtGA2ox4 and PtGA2ox 5 genes belonging to the poplar $\mathrm{C} 19$ gibberellin 2-oxidase (GA2ox) gene subfamily which primarily expressed in aerial organs led to significant increase of leaf size $(+50 \%)$, stem height $(+20 \%)$, diameter $(+10 \%)$ and biomass $(+30 \%)$ in Populus. It had no effect on the root development [22]. Transplastomic tobacco plants expressing $\beta$-glucosidase $(B g l-1)$, as compared with untransformed plants, have shown 2-fold higher gibberellin (of both GA1 and GA4 levels) in leaves but not in other organs. The elevated levels of other plant hormones, including zeatin and indole-3acetic acid, are observed in BGL-1 lines. These plants flowered 1 month earlier with an increase in biomass (1.9-fold), height (1.5-fold), and leaf area (1.6-fold) in comparison with untransformed plants [13].

The increase in organ size due to enhanced cell proliferation, without contribution from cell expansion was observed in Arabidopsis and tobacco plants expressing ARGOS (full-length cDNA from Chinese cabbage and $A$. thaliana leaves, respectively) gene [23, 24].

Significant axillary bud outgrowth at all nodes on the main stem with the pronounced branch development from the more basal nodes was observed in narrow-leafed lupin (Lupinus angustifolius L. cv Merrit) transgenic lines with isopentenyl transferase (ipt) gene from Agrobacterium tumefaciens coupled to a flowerspecific promoter (TP12) from N. tabacum [25]. IPT expression increased cytokinin levels in flowers, meristem tissues and phloem exudates in a form specific manner. The total number of pod set in some transgenic lines was increased and grain size was not significantly altered compared to control. In transgenic tobacco expressing fused AOC-ipt gene, cytokinins increased only two to three fold, and the plants grew more vigorously than the $A O C$ (the allene oxide cyclase gene from the salt-tolerant plant Bruguiera sexangula, which displays salt tolerance) transgenic plants lacking the ipt gene [26]. It was reflected in rapid plant growth, longer flowering period, greater number of flowers, more seed product, and increased chlorophyll synthesis. Total dry weight increased in $A O C$-ipt tobacco up to 1.27-fold in comparison with control ones and retained at the control level in $A O C$ plants in nonstress greenhouse conditions.

In our experiments cyp11A1 canola (Brassica napus L.) plants expressing cytochrome $\mathrm{P} 450_{\mathrm{SCC}}$ from bovine adrenal cortex mitochondria produced increased fresh weight $(+33 \%)$ and total soluble proteins $(+71 \%)$ in comparison with the control ones in non-stress aseptic conditions [27]. In animals cytochrome $\mathrm{P} 450_{\mathrm{SCC}}$ catalyzes cholesterol oxidation with formation of pregnenolone [28]. Superoxide radicals are formed during these reactions. We detected SOD activity increase in leaves 
of some cyp 11A1 canola plants in optimal growth conditions when it was compared with untransformed ones.

The enhanced initial seminal root growth in transgenic rice (Oryza sativa L.) seedlings expressing sheep serotonin $N$-acetyltransferase (NAT) matched their increased root biomass [29]. NAT is believed to be a ratelimiting enzyme in the melatonin biosynthesis in animals. It has previously been shown that exogenous melatonin application enhances plant growth [30]. Among a number of actions, melatonin is a direct free radical scavenger and an indirect antioxidant [31].

Agrobacterium rhyzogenes-mediated transformation technique can be used for the plant biomass improvement. The increased dry weight was observed in rolAtransformed blue grama grass (Bouteloua gracilis $(\mathrm{H}$. B. K.) Lag. ex Steud.) plants under greenhouse conditions, it was mainly related to shoot growth [32]. Several liquorice Glycyrrhiza glabra L. hairy root clones bearing $\mathrm{rolB}$ gene were more branched and showed about 8 fold higher root biomass on solid medium than untransformed ones [33].

Arabidopsis lines overexpressing $p d x 2$ gene which is involved in the de novo vitamin B6 biosynthesis pathway in plants have considerably larger vegetative and floral organs and it is related to a general increase in total protein, lipid and carbohydrate content [34].

The STOREKEEPER (STK) family of DNAbinding proteins works as transcription factors and the ectopic expression of two stk-like genes from Arabidopsis, stk01 and stk03, in tobacco increased the number of vegetative internodes and promoted plant and leaf size, stem diameter and sturdiness [35].

Selective genes neither created significant unintended pleiotropic effects on gene expression nor led to increased biomass formation [36, 37]. In some experiments the plants bearing vector with only selective gene were used as control ones. Any observations about biomass increase were fixed ([13] - nptII gene,[38] - bar gene). We did not also detect differences in biomass production between untransformed and transgenic canola plants simultaneously expressing nptII and promotorless bar genes [39].

Genetic engineering approaches allow reaching more than 2-fold biomass increase in model as well as in crop plants under both optimal controlled (greenhouse or growth chamber) and field conditions (Table 1).
Advantages under stress conditions. The expression of majority of genes which are mentioned in this chapter gives the advantages for transgenic plants under stress growth. These plants often do not differ from control ones in the optimal conditions. Both transgenic and initial plants reduce biomass production under stress influences. Transgenesis leads to new mechanisms of complex resistance to stresses of different origin and this knowledge provides creating the plants with high productivity under unfavorable conditions.

The rate of photosynthesis declines at moderately high temperatures. This can be attributed to a reduced ability of Rubisco activase to achieve optimum activation of Rubisco, which causes lower Rubisco activity. Transgenic Arabidopsis lines expressing chimeric activase (Rubisco recognition domain in more thermostable tobacco activase was replaced with that from Arabidopsis) showed higher rates of photosynthesis than the wild type after a short exposure to higher temperatures [44]. They also formed higher biomass and seed yield when compared with the wild type plants exposed to moderately elevated temperature.

Tobacco chloroplast engineering of $\beta$-alanine pathway by over-expression of the Escherichia coli panD gene, which catalyzed decarboxylation of 1-aspartate to generate $\beta$-alanine and carbon dioxide, enhances thermotolerance of photosynthesis and biomass production following high temperature stress [45].

Limited availability of phosphate ion $\left(\mathrm{P}_{i}\right)$ and nitrogen reduces plant growth in natural ecosystems. Compared with wild-type plants, the transgenic canola overexpressed barley alanine aminotransferase (AlaAT) driven by canola root specific promoter (btg26), had increased biomass (FW 1.98 fold, DW 1.75 fold) and seed yield in both laboratory and field under low nitrogen conditions, whereas no differences were observed under high nitrogen [46]. These changes resulted in a $40 \%$ decrease in the amount of applied nitrogen fertilizer required under field conditions to achieve the yields equivalent to wild-type plants.

Phosphorus (P) is an essential nutrient for the plant growth and development, but is generally unavailable and inaccessible in soil, since applied $\mathrm{P}$ is mostly fixed to aluminium $(\mathrm{Al})$ and ferrum $(\mathrm{Fe})$ in acidic soils and to calcium $(\mathrm{Ca})$ in alkaline soils. Increased organic acid excretion is one of the mechanisms by which plants use 
Table 1

Biomass increase in transgenic plants under normal growth conditions

\begin{tabular}{|c|c|c|c|}
\hline Species & Gene(s) & Increase, up fold & References \\
\hline \multirow[t]{2}{*}{ Arabidopsis } & The overexpression of $\boldsymbol{A t P A P 2}$, a purple acid phosphatase & 2 (total FW) & [18] \\
\hline & Full-length cDNA from Chinese cabbage leaves, $\boldsymbol{B r} \boldsymbol{A R G O S}$ & 2.2 (leaf FW) & {$[23]$} \\
\hline \multirow[t]{2}{*}{$\begin{array}{l}\text { Tobacco (Nicotiana } \\
\text { tabacum) }\end{array}$} & $\begin{array}{c}\text { Simultaneous UDP-glucose pyrophosphorylase (UGPase), sucrose } \\
\text { synthase (SuSy) and sucrose phosphate synthase (SPS) } \\
\text { overexpression }\end{array}$ & 1.5 (height growth) & {$[17]$} \\
\hline & $\begin{array}{l}\text { Isopentenyl transferase gene (ipt) downstream transcriptionally } \\
\text { fused with } \boldsymbol{A O C} \text { (allene oxide cyclase gene from the salt-tolerant } \\
\text { plant Bruguiera sexangula, which displays salt tolerance) gene } \\
\qquad(\boldsymbol{A O C} \text {-ipt) }\end{array}$ & 1.27 (total DW) & {$[26]$} \\
\hline $\begin{array}{l}\text { Transplastomic } \\
\text { tobacco (Nicotiana } \\
\text { tabacum L.) }\end{array}$ & $\beta$-glucosidase $(\boldsymbol{B} \boldsymbol{g} \boldsymbol{l}-\mathbf{1})$ & $\begin{array}{l}1.9 \text { (total FW); } 1.5 \text { (height); } \\
1.6 \text { (leaf area) }\end{array}$ & {$[13]$} \\
\hline $\begin{array}{l}\text { Rice Oryza sativa L. } \\
\text { cv. Taichung } 65\end{array}$ & $\begin{array}{l}\text { Partial suppression of endogenous OsBRI1 (a rice } \\
\text { BRASSINOSTEROID INSENSITIVE1 ortholog) }\end{array}$ & 1.3 (grain yield) & {$[40]$} \\
\hline Rice & Expression of the Arabidopsis HARDY (HRD) gene & $2($ total FW) & {$[41]$} \\
\hline Rice cv. Dongjin & Expression of the sheep serotonin $N$-acetyltransferase $(\boldsymbol{N} \boldsymbol{A} \boldsymbol{T})$ & $1.44(\operatorname{root} \mathrm{FW})$ & {$[29]$} \\
\hline Canola cv. Mariia & $\begin{array}{c}\text { cyp11A1 gene encoding cytochrome } \mathrm{P}^{4} 50_{\mathrm{SCC}} \text { from bovine adrenal } \\
\text { cortex mithochondria }\end{array}$ & $\begin{array}{l}1.33 \text { (total FW); } 1.71 \text { (total } \\
\text { soluble protein) in vitro }\end{array}$ & {$[27]$} \\
\hline $\begin{array}{l}\text { Common wheat } \\
\text { (Triticum aestivum L.) }\end{array}$ & $\begin{array}{l}\text { RNAi-mediated down-regulation of Glucan, Water-Dikinase } \\
\text { (GWD), the primary enzyme required for starch phosphorylation, } \\
\text { under the control of an endosperm-specific promoter }\end{array}$ & $\begin{array}{l}1.29 \text { (grain yield) in } \\
\text { glasshouse pot trials }\end{array}$ & {$[19]$} \\
\hline $\begin{array}{l}\text { Common wheat cv. } \\
\text { Hi-Line }\end{array}$ & $\begin{array}{c}\boldsymbol{H} \boldsymbol{V} \boldsymbol{A} \mathbf{1} \text { gene, encoding a group } 3 \text { LEA } \\
\text { protein from barley (Hordeum vulgare L.) }\end{array}$ & $1.1($ total DW) & {$[42]$} \\
\hline $\begin{array}{l}\text { Switchgrass (Panicum } \\
\text { virgatum L.) }\end{array}$ & $\begin{array}{c}\text { miR156 suppression of SQUAMOSA PROMOTER BINDING } \\
\text { PROTEIN LIKE }(\boldsymbol{S P L})\end{array}$ & $1.63-2.01($ total DW) & {$[43]$} \\
\hline $\begin{array}{l}\text { Blue grama grass } \\
\text { (Bouteloua gracilis) }\end{array}$ & $\begin{array}{l}\text { rolA gene of } A \text {. rhizogenes, under the control of a double } \\
\text { cauliflower mosaic virus (CaMV) } 35 \mathrm{~S}\end{array}$ & $\begin{array}{l}2 \text { (total DW) under } \\
\text { greenhouse conditions }\end{array}$ & {$[32]$} \\
\hline $\begin{array}{l}\text { Liquorice Glycyrrhiza } \\
\text { glabra }\end{array}$ & rolB gene of $A$. rhizogenes, under the control of nos promoter & 8 (hairy root $\mathrm{FW}$ ) in vitro & {$[33]$} \\
\hline $\begin{array}{l}\text { Poplar (hybrid clone } \\
\text { INRA } 717-\text { IB } 4(P o p u- \\
\text { lus tremula } \times P \text {. alba })\end{array}$ & $\begin{array}{l}\text { Suppression of } \boldsymbol{P t G A 2 o x} 4 \text { and } \boldsymbol{P t G} \boldsymbol{A} 2 \boldsymbol{2} \boldsymbol{x} 5 \text { genes belonging to the } \\
\text { poplar C19 gibberellin 2-oxidase }(\boldsymbol{G} \boldsymbol{A} 2 \boldsymbol{2} \boldsymbol{x}) \text { gene subfamily }\end{array}$ & $\begin{array}{l}1.5 \text { (leaf size); } 1.2 \text { (stem } \\
\text { height); } 1.1 \text { (stem diame- } \\
\text { ter); } 1.3 \text { (leaf FW) }\end{array}$ & {$[22]$} \\
\hline $\begin{array}{l}\text { Cotton Gossypium } \\
\text { hirsutum L. accession } \\
7235 \text { and TM-1 }\end{array}$ & $\begin{array}{l}\text { Overexpression of sucrose synthase (Sus } \boldsymbol{A} \mathbf{1}) \text { gene from a superior } \\
\text { quality fiber germplasm line } 7235 \text { of Gossypium hirsutum }\end{array}$ & $\begin{array}{l}1.4 \text { (total DW in both } \\
\text { seedling and boll stages of } \\
\text { development) }\end{array}$ & {$[20]$} \\
\hline
\end{tabular}

*FW - fresh weight; DW - dry weight.

to enhance $\mathrm{P}$ uptake. Overexpressing the mitochondrial malate dehydrogenase $(M D H)$ gene from the mycorrhizal fungi Penicillium oxalicum transgenic tobacco lines which showed the highest level of MDH activity and malate exudate were characterized by a significant increase in growth over wild-type [47]. The construction of a new citrate synthesis pathway by simultaneous overexpression of own citrate synthase and a mutant (with reduced sensitivity to organic acid inhibition) phosphoenolpyruvate carboxylase from Synechococ- 


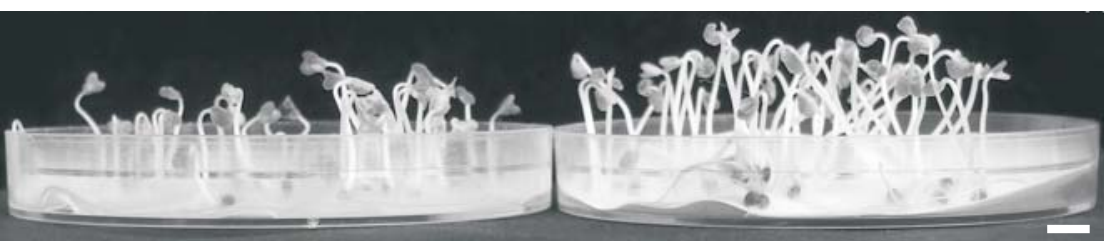

Bn 12

$T, 2 c$

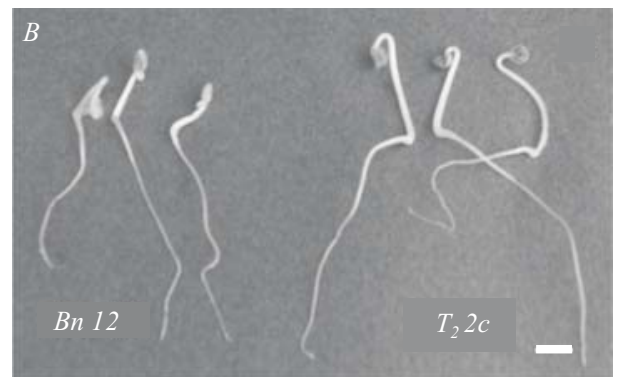

Control (Bn12) and cyp11A1 expressing cytochrome $\mathrm{P}_{450_{\mathrm{scc}}}$ from bovine adrenal cortex mitochondria $\left(\mathrm{T}_{2} 2 \mathrm{c}\right)$ seedling growth under high temperature $\left(26^{\circ} \mathrm{C}\right.$, thermostat): $A$ - forth germination day; $B$ - third germination day. Scale bars: $1 \mathrm{~cm}$

cus vulcanus in the cytoplasm of transgenic tobacco leaves led to an enhanced $\mathrm{Al}$ resistance in plants [48].

The biomass of several MtPHYl (phytase, under control of the root-specific MtPHY1 promoter) alfalfa (Medicago sativa L.) lines was three times that of the control when plants were grown in sand supplied with phytate as the sole P source and two times when the plants were grown in natural soils without additional $\mathrm{P}$ supplement [49]. Over-expression of GmEXPB2 (a soybean b-expansin) gene resulted in $28 \%$ increase in soybean (Glycine max (L.) Merr.) fresh weight at low P [50].

Protein dephosphorylation mediated by protein phosphatases plays a major role in signal transduction of plant responses to environmental stresses. The fresh weight increase in transgenic Arabidopsis lines bearing Faseolus vulgaris phosphatase (PvPs2:1) was significantly larger than that in wild type plants at low and high P levels, especially at the latter, accompanying by the upper of total P content and total root length [51]. AtPAP18 (Arabidopsis purple acid phosphatase encoding gene) tobacco plants exhibited significant increase in the acid phosphatase activity leading to an improved biomass production in both $\mathrm{P}_{i}$-deficient and $\mathrm{P}_{i}$-sufficient conditions [52].

Transgenic canola, expressing the gene for the enzyme 1-aminocyclopropane-1-carboxylate (ACC) deaminase, and/or untransformed canola treated with Pseudomonas putida UW4, which expressed the same gene, had greater shoot biomass compared to the untransformed canola under the low flood-stress conditions [53].

Inositol polyphosphate kinase (IPK) participates in inositol metabolism, calcium signaling, stress response, gene transcription and other physiological and biochemical processes. Transgenic soybean plants with the ThIPK2 gene (IPK from Thellungiella halophila) dis- played water deficit-, salt- and oxidative-tolerance compared to untransformed controls [54]. Furthermore, the expression of ThIPK2 altered the ratio of fatty acid components in soybean seeds, resulting in an increase of oleic acid (C18:1). The seed size was also increased in the transgenic plants.

The ectopic antioxidant gene expression leads to an increased plant resistance to stress of different origin that is accompanied by the formation of a larger plant biomass. The first enzyme in the detoxifying process of reactive oxygen species which were generated as byproducts of fatty acid $\beta$-oxidation, photorespiration, photosynthesis, and environmental conditions such as extreme temperatures and/or water stress, especially in combination with high light intensities is superoxide dismutase (SOD). It converts superoxide radicals to hydrogen peroxide. Some independent transgenic alfalfa (M. sativa) plants heterologously expressing MnSOD in mitochondria or chloroplasts had twice the herbage yield of the control plants after one winter period of growth [55]. The transgenic canola which overexpressed wheat Mn SOD3.1 produced more vigorous seedlings under both normal and stress conditions [56].

In our experiments cyp $11 A 1$ canola plants expressing cytochrome $\mathrm{P} 450_{\mathrm{scC}}$ from bovine adrenal cortex mitochondria formed larger biomass during different ontogenetic stages compared with untransformed control [27, 57]. Some of transgenic lines formed seedlings with longer roots (by $50 \%$ ) and hypocotyles (by $85 \%$ ) during germination at high temperature (Figure) [57].

Dehydroascorbate reductase (DHAR) maintains redox pools of ascorbate (AsA) by recycling oxidized AsA to reduced AsA. OsDHAR1 rice significantly increased photosynthetic capacity and antioxidant enzyme 
activities under paddy field conditions [58]. It also improved grain yield and biomass due to the increase of culm and root weights and enhanced panicle and spikelet numbers.

Ascorbate oxidase is an apoplastic enzyme, which also controls the redox ascorbate pool. Tomato Solanum lycopersicum plants with decreased ascorbate oxidase activity due to RNA-interference formed a larger fruit yield under limited water and leaf removing [59]. The ascorbate oxidase plants also showed increase in stomatal conductance and leaf and fruit sugar content, as well as an altered apoplastic hexose:sucrose ratio.

Glycine betaine is an osmoprotectant that plays an important role and accumulates rapidly in many plants during salinity or drought stress. Choline monooxygenase $(\mathrm{CMO})$ is a major catalyst in the synthesis of glycine betaine. The seed cotton yield of the AhCMO (choline monooxygenase from Atriplex hortensis) plants was lower under normal conditions, but was significantly higher than that of non-transgenic plants under the saltstressed field conditions [60]. Common wheat lines that were transgenic for the betA gene encoding choline dehydrogenase from $E$. coli were less injured and exhibited greater root length and growth compared with the wild type under drought stress [61].

Glutathione (GSH), a low-molecular-weight tripeptide molecule, that plays an important role in cell function and metabolism as an antioxidant, is synthesized by $\gamma$-glutamylcysteine synthetase $(\gamma$-ECS) and glutathione synthetase (GS). The transgenic rice plants expressing the ECS gene from Brassica juncea $\mathrm{L}$. under the regulation of a stress-inducible Rab21 promoter displayed a moderate increase in biomass (up to 1.2 times in total FW and 1.1 fold in root $\mathrm{FW}$ ) and rice grain yield (up 1.2 fold in total seed weight) under general paddy field conditions [62].

AlSAP (stress-associated protein from the halophyte grass Aeluropus littoralis) durum wheat (Triticum durum) of the commercial cv. Karim exhibited improved germination rates and biomass production under salinity and osmotic stress conditions [63]. Following longterm salt or drought stress greenhouse trials, AlSAP lines produced normally filled grains whereas wild-type plants either died at the vegetative stage under the salt stress or showed markedly reduced grain filling under the drought stress.
Isopentenyltransferase (IPT) is a critical enzyme in the cytokinin biosynthetic pathway. The ipt expression under the control of a maturation- and stress-induced SARK promoter delayed stress-induced plant senescence that resulted in an enhanced drought tolerance in peanut (Arachis hypogaea L.) in both laboratory and field conditions [64]. The transgenic peanut plants maintained 2 fold higher photosynthetic rates and transpiration than wild-type plants under the reduced irrigation conditions. More importantly, the ipt peanut plants produced significantly higher yields than wild-type plants in the field dryland (50 and $29 \mathrm{~g} /$ plant, respectively) while at high irrigation no significant yield differencies were observed between the transgenic and initial plants (42 and $40 \mathrm{~g} /$ plant, respectively).

The $A O C$ gene plays a role in salt tolerance. When the ipt gene transcriptionally fused with $A O C$ in the frame of $A O C$-ipt, slight cytokinin increases were obtained in these transgenic plants which played a positive role in improvement of plant growth. Dry weight was increased in the $p V K H 35 S$ - $A O C$ and $p V K H 35 S$-AOC-ipt up to 1.12 times and 1.39 fold, respectively, in comparison with the control plants under drought in a greenhouse. It was more prominent under high salinity when plants were watered by sea water and increase in the plant dry weight reached up to 1.59 and 1.37 times ( $p V K H 35 S$-AOC-ipt and $p V K H 35 S-A O C$, respectively) [26].

As an innate and adaptive response to water deficit, land plants avoid potential damage by rapid biosynthesis of the abscisic acid (ABA), which triggers stomatal closure to reduce transpirational water loss. Recent genetic studies have pinpointed protein farnesyltransferase as a key negative regulator controlling ABA sensitivity in the guard cells. Conditional and specific downregulation of farnesyltransferase in canola using the Arabidopsis hydroxypyruvate reductase promoter driving an RNAi construct resulted in yield protection against drought stress in the field [10]. There was no significant difference in growth and agronomic performance between the genetically engineered transgenic canola and its wild-type control in optimal conditions. However, under the moderate drought stress conditions at flowering, the transgenic plants produced significantly higher seed yield.

High ectopic expression of the tomato abscisic acidinduced myb1 (SlAIM1) gene encoding the R2R3MYB 


\section{Table 2}

Transgenic plant advantages in biomass production in different stress conditions

\begin{tabular}{|c|c|}
\hline Species & Gene(s) \\
\hline $\begin{array}{l}\text { Arabidopsis } \\
\text { Arabidopsis thaliana L. }\end{array}$ & Faseolus vulgaris phosphatase (PvPs2:1) \\
\hline \multirow[t]{4}{*}{$\begin{array}{l}\text { Tobacco Nicotiana } \\
\text { tabacum L. }\end{array}$} & $\begin{array}{c}\text { Arabidopsis purple acid phosphatase encoding } \\
\text { gene, } \boldsymbol{A t P A P 1 8}\end{array}$ \\
\hline & $\begin{array}{l}\text { Mitochondrial malate dehydrogenase }(\boldsymbol{M D H}) \text { gene } \\
\text { from the mycorrhizal fungi Penicillium oxalicum }\end{array}$ \\
\hline & The same \\
\hline & The same \\
\hline
\end{tabular}

The Escherichia coli 1-aspartate- $\alpha$-decarboxylase (AspDC) encoded by the panD gene

1) Phosphoenolpyruvate carboxylase (pepc); 2) citrate synthase $(\boldsymbol{c s}) ; 3$ ) double transformants

$A O C$-ipt-isopentenyl transferase gene (ipt) downstream transcriptionally fused with $\boldsymbol{A O C}$

(allene oxide cyclase gene from Bruguiera sexangula, which displays salt tolerance) gene

Alfalfa cv. Regen SY-4D

\section{Alfalfa}

Rice cv. Ilmi

Rice cv. Nipponbare

Durum wheat (Triticum durum) commercial cv. Karim

Common wheat (Triticum aestivum L.) cv. Jinan 17

Canola cv. Westar under the root-specific MtPT1 promoter

\section{The same}

$\mathbf{M n - S O D}$ in mitochondria or chloroplast

Brassica juncea $\gamma$-glutamylcysteine synthetase $(\boldsymbol{B r E C S})$ gene under the regulation of a stress-inducible Rab21 promoter

Arabidopsis HARDY (HRD) gene, an AP2/ERF-like transcription factor

$\boldsymbol{A l S A P}$ (stress-associated protein) gene from the halophyte grass Aeluropus littoralis

\section{The same}

bet $\boldsymbol{A}$ encoding choline dehydrogenase from

$$
\text { Escherichia coli }
$$

Barley alanine aminotransferase $(\boldsymbol{A l a} \boldsymbol{A} \boldsymbol{T})$ under canola root specific promoter (btg26)

1-Aminocyclopropane-1-carboxylate $(\boldsymbol{A C C})$ deaminase from Pseudomonas putida UW4 under control of the rolD promoter from Agrobacterium rhizogenes
Phytase (MtPHY1) gene from Medicago truncatula
High P level $\quad 1.2$ (total FW)

In both $\mathrm{P}_{i}$-deficient and $\mathrm{P}_{i}$-sufficient conditions

1.41 (total FW)

Al-phosphate medium

1.49 (total FW)

Fe-phosphate medium

1.29 (total FW)

Ca-phosphate medium

1.28 (total FW)

High temperature

1.3-1.4 (total FW)

1) 1.2 ; 2) 1.49;

Al stress

3) 1.82 (height);

1) 1.33 ; 2) 2.55 ;

3) 3.73 (root DW)

Drought stress

1.39 (total DW)

In natural soils without additional Phosphorus supplement

2 (total FW)

With phytate as the sole P source

3 (total FW)

Cold stress

$2($ total FW)

Osmotic stress

(100 mM NaCl)

1.2 (total FW); 1.1

(root FW); 1.2

(total seed weight)

Drought stress

1.5 (total FW) in greenhouse

Osmotic stress (50 mM NaCl)

3 (leaf DW)

Osmotic stress

(150 mM NaCl)

4 (leaf DW)

Drought stress

1.36 (total DW)

1.98 (total FW)

Low nitrogen $\quad 1.75$ (total DW)

Low flood stress

1.34 (total DW) in field conditions 


\begin{tabular}{|c|c|c|c|c|}
\hline Species & Gene(s) & Conditions & Increase, up fold & $\begin{array}{l}\text { Referen- } \\
\text { ces }\end{array}$ \\
\hline Canola cv. Westar & $\begin{array}{c}\text { 1-Aminocyclopropane-1-carboxylate }(\boldsymbol{A C C}) \\
\text { deaminase }+ \text { Pseudomonas putida UW4, which } \\
\text { also expresses ACC deaminase }\end{array}$ & Low flood stress & $\begin{array}{l}1.38 \text { (control total } \\
\text { DW)-1.31 (trans- } \\
\text { genic total DW) in } \\
\text { field conditions }\end{array}$ & {$[53]$} \\
\hline $\begin{array}{l}\text { Canola doubled haploid } \\
\text { line DH-12075 }\end{array}$ & $\begin{array}{l}\text { Wheat mitochondrial Mn superoxide dismutase } \\
\qquad(\text { Mn SOD3.1) }\end{array}$ & $\begin{array}{l}\text { Cold, drought, high } \\
\text { temperature (field and } \\
\text { in vitro) }\end{array}$ & 1.4 (total FW) & {$[56]$} \\
\hline \multirow[t]{2}{*}{ Canola cv. Mariia } & $\begin{array}{l}\text { cyp11A1 gene encoding cytochrome } \mathrm{P} 450_{\mathrm{SCC}} \text { from } \\
\text { bovine adrenal cortex mithochondria }\end{array}$ & $\begin{array}{l}\text { Osmotic stress ( } 500 \mathrm{mM} \\
\text { mannitol) in vitro }\end{array}$ & $2($ total FW) & {$[27]$} \\
\hline & The same & High temperature & 1.31 (total FW) & {$[57]$} \\
\hline Canola cv. Youyan N 9 & Brassica napus heme oxygenase (BHO-1) & $\mathrm{Hg}$ stress & $\begin{array}{l}1.41-1.50(\text { total } \\
\text { DW) }\end{array}$ & [69] \\
\hline $\begin{array}{l}\text { Tomato (Solanum } \\
\text { lycopersicum) cvs } \\
\text { CastlemartII and } \\
\text { Micro-Tom }\end{array}$ & $\begin{array}{l}\text { The tomato abscisic acid-induced } m y b 1 \text { (SIAIM1) } \\
\text { gene encoding an R2R3MYB transcription factor }\end{array}$ & $\begin{array}{c}\text { Osmotic stress } \\
(200-250 \mathrm{mM} \mathrm{NaCl})\end{array}$ & 1.1 (total FW) & {$[65]$} \\
\hline $\begin{array}{l}\text { Sugar beet (Beta vulgaris } \\
\text { L.) cv. Heitian N } 1\end{array}$ & $\begin{array}{c}\text { An Arabidopsis thaliana vacuolar } \mathrm{Na}^{+} / \mathrm{H}^{+} \\
\text {antiporter gene, } \boldsymbol{A t} \mathbf{N H X} \mathbf{3}\end{array}$ & $\begin{array}{l}\text { Osmotic stress } \\
(500 \mathrm{mM} \mathrm{NaCl})\end{array}$ & $\begin{array}{c}2(\text { total DW); } 2.2 \\
(\text { total FW }) ; 2.2 \\
\text { (storage root DW) }\end{array}$ & {$[70]$} \\
\hline $\begin{array}{l}\text { Soybean (Glycine } \max \\
\text { (L.) Merr.) cv. HN89 }\end{array}$ & A soybean $\beta$-expansin $(\boldsymbol{G} \boldsymbol{m} \boldsymbol{E} \boldsymbol{X P B} 2)$ gene & Low P level & $1.28($ total FW) & {$[50]$} \\
\hline $\begin{array}{l}\text { Peanut (Arachis } \\
\text { hypogaea L.) New } \\
\text { Mexico Valencia A }\end{array}$ & $\begin{array}{l}\text { Isopentenyltransferase }(\boldsymbol{I P T}) \text { under the control of a } \\
\text { maturation- and stress-induced promoter }\left(\mathrm{P}_{\text {sark }}\right)\end{array}$ & Drought stress & $\begin{array}{l}\text { 1.84-1.61 (shoot } \\
\text { FW-DW); 2.88- } \\
2.24 \text { (root FW-DW) } \\
\text { in growth chamber }\end{array}$ & [64] \\
\hline
\end{tabular}

transcription factor resulted in reduced plant growth compared with the control plants under normal growth conditions [65].

However, the 35S:SlAIM1 plants grow significantly better than the wild-type controls under high salinity, and only marginally lower than the 35S: S1AIM1 plants grown without salt stress.

Different plants exhibit different, sometimes opposite, response to the same foreign gene introduction. Expression of $\Delta^{1}$-pyrroline-5-carboxylate synthetase (P5CS) from mothbean (Vigna aconitifolia L.) under the control of a stress-inducible promoter led to stress-induced overproduction of the P5CS enzyme and proline accumulation in the transgenic rice plants [66]. Second-generation plants showed an increase in biomass under saltand water-stress conditions as compared to the untransformed plants. But biomass increase in chickpea (Cicer arietinum L.), which accumulated proline (up to 6fold) due to mutagenized P5CS expression, was not do- cumented [67]. Authors supposed that the enhanced proline level had little bearing on the components of yield architecture that are significant in overcoming the negative effects of drought stress in chickpea.

The transformation of dicots with the rolA gene results in the shortened internode length, green darkened leaves, reduced apical dominance, leaf wrinkling, decreased length-to-width leaf ratio, shortened styles, larger flower size, reduced flower number, condensed inflorescences, male sterility, and retarded onset of flowering [68]. The rolA B. gracilis (the important forage grass) lines showed a 2-fold reduced root system, but they produced up to twice as much foliage as control plants due to enhanced height (up 1.3 fold) and increased tillering and leaf number (up to 1.7 and 1.5 fold, respectively) [32].

Transgenesis allows reach up to 2 fold biomass increase versus the untransformed (wild type or tissue culture) plants in stress (Table 2). 
Conclusions. Genetic engineering approaches allow reaching more than 2-fold biomass increase in model as well as in crop plants under optimal conditions. Transgenesis can reveal the new mechanisms of complex resistance to stresses of different origin and this knowledge may be used to create plants with high productivity under unfavorable conditions. It leads to reduced biomass losses under stress nearly 2-fold. Overexpression of some genes of phosphorus and nitrogen metabolism offers an effective approach for reducing the consumption of chemical fertilizers through increased acquisition of soil nutrients and mobilization of internal resources. In recent years the significant amount of studies have been focused at crops such as canola, rice and wheat under field conditions. It should facilitate the introduction of these developments in the agriculture practice.

Acknowledgements. Author is most grateful to Dr. Valeriia Belokurova (Institute of Cell Biology and Genetic Engineering, NAS of Ukraine) for critical review of the manuscript.

\section{Л. О. Сахно}

Збільшення біомаси рослин: останні досягнення генетичної інженерії

\section{Резюме}

Вирішення завдань збільшення біомаси рослин з використанням трансгенезу роглянуто як на модельних об 'ектах, так $і$ на прикладах сільськогосподарських культур, вирощуваних за оптимальних i контрольованих стресових (теплиця або клімакамера) та польових умов. Показано, щуо генно-інженерні підходи дозволяють досягти подвоєння біомаси за оптимальних умов. І трансгенні, $і$ вихідні рослини зменшують накопичення біомаси внаслідок дї стресових факторів. Продемонстровано, щьо трансгенні рослини здатні збільшувати свою продуктивність до двох разів порівняно з нетрансформованими за умов стресу. Обговорюються деякі особливості гетерологічної експресї генів, які впливають на накопичення біомаси.

Ключові слова: біомаса, стрес, суха маса, сира маса, трансгенні рослини

\section{Л. А. Сахно}

Увеличение биомассы растений: последние достижения генетической инженерии

\section{Резюме}

Решение задачи увеличения биомассы растений с использованием трансгенеза рассмотрено как на модельных объектах, так и на примерах сельскохозяйственных культур, вырашиваемых в оптимальных и контролируемых стрессовых (теплица или климакамера), а также полевых условиях. Показано, что генно-инженерные подходы позволяют достичь удвоения биомассы при оптимальныхх условиях. И трансгенные, и исходные растения уменьшают накопление биомассы в результате действия стрессовых факторов. Продемонстрировано, что в условиях стресса трансгенные растения способны увеличивать свою продуктивность до двух раз по сравнению с нетрансформированными. Обсуждаются некоторые особенности гетерологической экспрессии генов, влияюшие на накопление биомассы.

Ключевые слова: биомасса, стресс, сухая масса, сырая масса, трансгенные растения.

\section{REFERENCES}

1. Ragauskas A. J., Williams C. K., Davison B. H., Britovsek G., Cairney J., Eckert C. A., Frederick W. J. Jr., Hallett J. P., Leak D. J., Liotta C.L., Mielenz J. R., Murphy R., Templer R., Tschaplinski $T$. The path forward for biofuels and biomaterials // Science.-2006.-311, N 5759.-P. 484-489.

2. Demura T., Ye Z. H. Regulation of plant biomass production // Curr. Opin. Plant Biology.-2010.-13, N 3.-P. 299-304.

3. Crawford N. M. Nitrate: nutrient and signal for plant growth // Plant Cell.-1995.-7, N 7.-P. 859-868.

4. Vance C. P., Uhde-Stone C., Allan D. L. Phosphorus acquisition and use: critical adaptations by plants for securing a non-renewable resource// New Phytol.-2003.-157, N 3.-P. 423-447.

5. Dechorgnat J., Nguyen C. T., Armengaud P., Jossier M., Diatloff E., Filleur S., Daniel-Vedele F. From the soil to the seeds: the long journey of nitrate in plants // J. Exp. Bot.-2011.-62, N 4.P. 1349-1359.

6. McAllister C. H., Beatty P. H., Good A. G. Engineering nitrogen use efficient crop plants: the current status // Plant Biotechnol. J.-2012.-10, N 9.-P. 1011-1025.

7. Peterhansel C., Niessen M., Kebeish R. M. Metabolic engineering towards the enhancement of photosynthesis // Photochem. Photobiol.-2008.-84, N 6.-P. 1317-1323.

8. Poorter H., Niklas K. J., Reich P. B., Oleksyn J., Poot P., Mommer $L$. Biomass allocation to leaves, stems and roots: meta-analyses of interspecific variation and environmental control // New Phytol.2012.-193, N 1.-P. 30-50.

9. Zhao B., Li J. Regulation of brassinosteroid biosynthesis and inactivation // J. Integr. Plant Biol.-2012.-54, N 10.-P. 746-759.

10. Wang Y., Beaith M., Chalifoux M., Ying J., Uchacz T., Sarvas C., Griffiths R., Kuzma M., Wan J., Huang Y. Shoot-specific downregulation of protein farnesyltransferase (alpha-subunit) for yield protection against drought in canola // Mol. Plant.-2009.-2, N 1.P. 191-200.

11. Eriksson M. E., Israelsson M., Olsson O., Moritz T. Increased gibberellin biosynthesis in transgenic trees promotes growth, biomass production and xylem fiber length // Nat. Biotechnol.2000.-18, N 7.-P. 784-788.

12. Kakimoto T. Perception and signal transduction of cytokinins // Annu. Rev. Plant Biol.-2003.-54.-P. 605-627.

13. Jin S., Kanagaraj A., Verma D., Lange T., Daniell H. Release of hormones from conjugates: chloroplast expression of $\beta$-glucosidase results in elevated phytohormone levels associated with significant increase in biomass and protection from aphids or whiteflies conferred by sucrose esters // Plant Physiol.-2011.155, N 1.-P. 222-235.

14. Pilon-Smits E., Ebskamp M., Paul M. J., Jeuken M., Weisbeek P. $J$., Smeekens $S$. Improved performance of transgenic fructan-accumulating tobacco under drought stress // Plant Physiol.1995.-107, N 1.-P. 125-130.

15. Rook F., Corke F., Baier M., Holman R., May A. G., Bevan M. W. Impaired sucrose induction 1 encodes a conserved plant-specific 
protein that couples carbohydrate availability to gene expression and plant growth // Plant J.-2006.-46, N 6.-P. 1045-1058.

16. Patrick J. W., Botha F. C., Birch R. G. Metabolic engineering of sugars and simple sugar derivatives in plants // Plant Biotechnol. J.-2013.-11, N 2.-P. 142-156.

17. Coleman H. D., Beamish L., Reid A., Park J. Y., Mansfield S. D. Altered sucrose metabolism impacts plant biomass production and flower development // Transgenic Res.-2010.-19, N 2.P. 269-283.

18. Sun F., Suen P. K., Zhang Y., Liang C., Carrie C., Whelan J., Ward J. L., Hawkins N. D., Jiang L., Lim B. L. A dual-targeted purple acid phosphatase in Arabidopsis thaliana moderates carbon metabolism and its overexpression leads to faster plant growth and higher seed yield // New Phytol.-2012.-194, N 1.-P. 206-219.

19. Ral J.-P., Bowerman A. F., Li Z., Sirault X., Furbank R., Pritchard J. R., Bloemsma M., Cavanagh C. R., Howitt C. A., Morell $M$. $K$. Down-regulation of Glucan, Water-Dikinase activity in wheat endosperm increases vegetative biomass and yield // Plant Biotechnol. J.-2012.-10, N 7.-P. 871-882.

20. Jiang Y., Guo W., Zhu H., Ruan Y.-L., Zhang T. Overexpression of GhSusA1 increases plant biomass and improves cotton fiber yield and quality // Plant Biotechnol. J.-2012.-10, N 3.-P. 301-312.

21. Dayan J., Schwarzkopf M., Avni A., Aloni R. Enhancing plant growth and fiber production by silencing GA 2-oxidase // Plant Biotechnol. J.-2010.-8, N 4.-P. 425-435.

22. Gou J., Ma C., Kadmiel M., Gai Y., Strauss S., Jiang X., Busov V. Tissue-specific expression of Populus C19 GA 2-oxidases differentially regulate above- and below-ground biomass growth through control of bioactive GA concentrations // New Phytol.2011.-192, N 3.-P. 626-639.

23. Wang B., Zhou X., Xu F., Gao J. Ectopic expression of a Chinese cabbage BrARGOS gene in Arabidopsis increases organ size // Transgenic Res.-2010.-19, N 3.-P. 461-472.

24. Kuluev B. R., Knyazev A. V., Iljassowa A. A., Chemeris A. V. Constitutive expression of the $A R G O S$ gene driven by dahlia mosaic virus promoter in tobacco plants // Russ. J. Plant Physiol.2011.-58, N 3.-P. 507-515.

25. Atkins C. A., Emery R. J., Smith P. M. Consequences of transforming narrow leafed lupin (Lupinus angustifolius [L.]) with an ipt gene under control of a flower-specific promoter // Transgenic Res.-2011.-20, N 6.-P. 1321-1332.

26. Guo J.-C., Duan R.-J., Hu X.-W., Li K.-M., Fu S.-P. Isopentenyl transferase gene (ipt) downstream transcriptionally fused with gene expression improves the growth of transgenic plants // Transgenic Res.-2010.-19, N 2.-P. 197-209.

27. Trehub M. S., Sakhno L. O. Growth features of the transgenic Brassica napus plants expressing cytochrome $\mathrm{P}^{4} 50_{\mathrm{SCC}}$ cyp $11 \mathrm{Al}$ gene under in vitro osmotic stress conditions // Achievements and Problems of Genetics, Breeding and Biotechnology / Ed. V. A. Kunah.-Kyiv: Logos, 2012.-Vol. 4.-P. 623-628.

28. Chung B. C., Matteson K. J., Voutilainen R., Mohandas T. K., Miller W. L. Human cholesterol side-chain cleavage enzyme, P450scc: cDNA cloning, assignment of the gene to chromosome 15, and expression in the placenta // Proc. Natl Acad. Sci. USA.-1986.83, N 23.-P. 8962-8966.

29. Park S., Back K. Melatonin promotes seminal root elongation and root growth in transgenic rice after germination // J. Pineal Res.2012.-53, N 4.-P. 385-389.

30. Posmyk M. M., Kuran H., Marciniak K., Janas K. M. Presowing seed treatment with melatonin protects red cabbage seedlings against toxic copper ion concentrations // J. Pineal Res.-2008.45, N 1.-P. 24-31.

31. Tan D.-X., Hardeland R., Manchester L. C., Korkmaz A., Ma S., Rosales-Corral S., Reiter R. J. Functional roles of melatonin in plants, and perspectives in nutritional and agricultural science // J Exp. Bot.-2012.-63, N 2.-P. 577-597.

32. Aguado-Santacruz G. A., Rascon-Cruz Q., Moreno-Gomez B., Guevara-Gonzalez R. G., Guevara-Olvera L., Jimenez-Bremont J. F., Arevalo-Gallegos S., Garcia-Moya E. Genetic transformation of blue grama grass with the rolA gene from Agrobacterium rhizogenes: regeneration of transgenic plants involves a «hairy embryo») stage // In Vitro Cell. Dev. Biol. Plant.-2009.-45, N 6.P. 681-692.

33. Tenea G. N., Calin A., Gavrila L., Cucu N. Manipulation of root biomass and biosynthetic potential of Glycyrrhiza glabra L. plants by Agrobacterium rhizogenes mediated transformation // Rom. Biotechnol. Lett.-2008.-13, N 5.-P. 3922-3932.

34. Raschke M., Boycheva S., Crevecoeur M., Nunes-Nesi A., Witt S. Fernie A. R., Amrhein N., Fitzpatrick T. B. Enhanced levels of vitamin B6 increase aerial organ size and positively affect stress tolerance in Arabidopsis // Plant J.-2011.-66, N 3.-P. 414-432.

35. Bomer M., Uhrig J. F., Jach G., Muller K. J. Increased vegetative development and sturdiness of storekeeper-transgenic tobacco // Cent. Eur. J. Biol.-2011.-6, N 3.-P. 342-351.

36. Manabe Y., Tinker N., Colville A., Miki B. CSR1, the sole target of imidazolinone herbicide in Arabidopsis thaliana // Plant Cell Physiol.-2007.-48, N 9.-P. 1340-1358.

37. Schnell J., Labbe H., Kovinich N., Manabe Y., Miki B. Comparability of imazapyr-resistant Arabidopsis created by transgenesis and mutagenesis // Transgenic Res.-2012.-21, N 6.-P. 1255-1264.

38. Spivak S. G., Berdichevets I. N., Yarmolinsky D. G., Maneshina T. V., Shpakovski G. V., Kartel N. A. Construction and characteristics of transgenic tobacco Nicotiana tabacum L. plants expressing CYP11A1 cDNA encoding cytochrome P450 ${ }_{\mathrm{SCC}} / /$ Russ. J. Genet.-2009.-45, N 9.-P. 1067-1073.

39. Sakhno L. A., Gocheva E. A., Komarnitskii I. K., Kuchuk N. V. Stable expression of the promoterless bar gene in transformed rapeseed plants // Cytol. Genet.-2008.-42, N 1.-P. 16-22.

40. Morinaka Y., Sakamoto T., Inukai Y., Agetsuma M., Kitano H., Ashikari M., Matsuoka M. Morphological alteration caused by brassinosteroid insensitivity increases the biomass and grain production of rice // Plant Physiol.-2006.-141, N 3.-P. 924-931.

41. Karaba A., Dixit S., Greco R., Aharoni A., Trijatmiko K. R., Marsch-Martinez N., Krishnan A., Nataraja K. N., Udayakumar $M$., Pereira A. Improvement of water use efficiency in rice by expression of HARDY, an Arabidopsis drought and salt tolerance gene // Proc. Natl Acad. Sci. USA.-2007.-104, N 39.-P. 1527015275.

42. Sivamani E., Bahieldin1 A., Wraith J. M., Al-Niemi T., Dyer W. E., Ho T. D., Qu R. Improved biomass productivity and water use efficiency under water deficit conditions in transgenic wheat constitutively expressing the barley HVAl gene // Plant Sci.2000.-155, N 1.-P. 1-9.

43. Fu C., Sunkar R., Zhou C., Shen H., Zhang Ji-Yi, Matts J., Wolf J., Mann D. G., Stewart C. N. Jr., Tang Y., Wang Z. Y. Overexpression of miR156 in switchgrass (Panicum virgatum L.) results in various morphological alterations and leads to improved biomass production // Plant Biotechol. J.-2012.-10, N 4.-P. 443-452.

44. Kumar A., Li C., Portis A. R. Jr. Arabidopsis thaliana expressing a thermostable chimeric Rubisco activase exhibits enhanced growth and higher rates of photosynthesis at moderately high temperatures // Photosynth. Res.-2009.-100, N 3.-P. 143-153.

45. Fouad W. M., Altpeter F. Transplastomic expression of bacterial 1-aspartate-alpha-decarboxylase enhances photosynthesis and biomass production in response to high temperature stress // Transgenic Res.-2009.-18, N 5.-P. 707-718.

46. Good A. G., Jonson S. J., de Pauw M., Carroll R. T., Savidov N., Vidmar J., Lu Z., Taylor G., Stroeher V. Engineering nitrogen use 
efficiency with alanine aminotransferase // Can. J. Bot.-2007.85, N 3.-P. 252-262.

47. Lu J., Gao X., Dong Z., Yi J., An L. Improved phosphorus acquisition by tobacco through transgenic expression of mitochondrial malate dehydrogenase from Penicillium oxalicum // Plant Cell Rep.-2012.-31, N 1.-P. 49-56.

48. Wang Q., Yi Q., Hu Q., Zhao Y., Nian H., Li K., Yu Y., Izui K., Chen $L$. Simultaneous overexpression of citrate synthase and phosphoenolpyruvate carboxylase in leaves augments citrate exclusion and Al resistance in transgenic tobacco // Plant Mol. Biol. Rep.-2012.-30, N 4.-P. 992-1005.

49. Ma X. F., Tudor S., Butler T., Ge Y., Xi Y., Bouton J., Harrison M., Wang $Z$. $Y$. Transgenic expression of phytase and acid phosphatase genes in alfalfa (Medicago sativa) leads to improved phosphate uptake in natural soils // Mol. Breed.-2012.-30, N 1.P. 377-391.

50. Guo W., Zhao J., Li X., Qin L., Yan X., Liao H. A soybean $\beta$-expansin gene GmEXPB2 intrinsically involved in root system architecture responses to abiotic stresses // Plant J.-2011.-66, N 3.P. 541-552.

51. Liang C. Y., Chen Z. J., Yao Z. F., Tian J., Liao H. Characterization of two putative protein phosphatase genes and their involvement in phosphorus efficiency in Phaseolus vulgaris // J. Integr. Plant Biol.-2012.-54, N 6.-P. 400-411.

52. Zamani K., Sabet M. S., Lohrasebi T., Mousavi A., Malboobi M. $A$. Improved phosphate metabolism and biomass production by overexpression of AtPAP18 in tobacco // Biologia.-2012.-67, N 4.-P. 713-720.

53. Farwell A. J., Vesely S., Nero V., Rodriguez H., McCormack K., Shah S., Dixon D. G., Glick B. R. Tolerance of transgenic canola plants (Brassica napus) amended with plant growth-promoting bacteria to flooding stress at a metal-contaminated field site / Environ. Pollut.-2007.-147, N 3.-P. 540-545.

54. Liu M., Li D., Wang Z., Meng F., Li Y., Wu X., Teng W., Han Y., $L i W$. Transgenic expression of ThIPK2 gene in soybean improves stress tolerance, oleic acid content and seed size // Plant Cell Tissue Organ. Cult.-2012.-111, N 3.-P. 277-289.

55. McKersie B. D., Bowley S. R., Jones K. S. Winter survival of transgenic alfalfa overexpressing superoxide dismutase // Plant Physiol.-1999.-119, N 3.-P. 839-847.

56. Gusta L. V., Benning N. T., Wu G., Luo X., Liu X., Gusta M. L., McHughen A. Superoxide dismutase: an all-purpose gene for agri-biotechnology // Mol. Breed.-2009.-24, N 2.-P. 103-115.

57. Sakhno $L$. $O$. Seed germination features of canola plants expressing mammalian cytochrome $\mathrm{P} 450_{\mathrm{SCC}}$ cypl1A1 gene // The Bulletin of Vavilov Society of Geneticists and Breeders of Ukraine.-2011.-9, N 2.-P. 253-259.

58. Kim Y. S., Kim I. S., Bae M. J., Choe Y. H., Kim Y. H., Park H. M., Kang H. G., Yoon H. S. Homologous expression of cytosolic dehydroascorbate reductase increases grain yield and biomass under paddy field conditions in transgenic rice (Oryza sativa $\mathrm{L}$. japonica) // Planta.-2013.-237, N 6.-P. 1613-1625.

59. Garchery C., Gest N., Do P. T., Alhagdow M., Baldet P., Menard G., Rothan C., Massot C., Gautier H., Aarrouf J., Fernie
A. R. Stevens $R$. A diminution in ascorbate oxidase activity affects carbon allocation and improves yield in tomato under water deficit // Plant Cell Environ.-2013.-36, N 1.-P. 159-175.

60. Zhang H., Dong H., Li W., Sun Y., Chen S., Kong X. Increased glycine betaine synthesis and salinity tolerance in $A h C M O$ transgenic cotton lines // Mol. Breed.-2009.-23, N 2.-P. 289-298.

61. He C., Zhang W., Gao Q., Yang A., Hu X., Zhang. J. Enhancement of drought resistance and biomass by increasing the amount of glycine betaine in wheat seedlings // Euphytica.-2011.-177, N 2.-P. 151-167.

62. Bae M.-J., Kim Y.-S., Kim I.-S., Choe Y.-H., Lee E.-J., Kim Y.-H., Park H.-M., Yoon H.-S. Transgenic rice overexpressing the Brassica juncea gamma-glutamylcysteine synthetase gene enhances tolerance to abiotic stress and improves grain yield under paddy field conditions // Mol. Breed.-2013.-31, N 4.-P. 931-945.

63. Ben-Saad R., Ben-Ramdhan W., Zouari N., Azaza J., Mieulet D., Guiderdoni E., Ellouz R., Hassairi A. Marker-free transgenic durum wheat cv. Karim expressing the AlSAP gene exhibits a high level of tolerance to salinity and dehydration stresses // Mol. Breed.-2012.-30, N 1.-P. 521-533.

64. Qin H., Gu Q., Zhang J., Sun L., Kuppu S., Zhang Y., Burow M., Payton P., Blumwald E., Zhang $H$. Regulated expression of an isopentenyltransferase gene (IPT) in peanut significantly improves drought tolerance and increases yield under field conditions // Plant Cell Physiol.-2011.-52, N 11.-P. 1904-1914.

65. AbuQamar S., Luo H., Laluk K., Mickelbart M. V., Mengiste T. Crosstalk between biotic and abiotic stress responses in tomato is mediated by the AIM1 transcription factor // Plant J.-2009.-58, N 2.-P. 347-360.

66. Zhu B., Su J., Chang M., Verma D. P. S., Fan Y.-L., Wu R. Overexpression of a $\Delta^{1}$-pyrroline-5-carboxylate synthetase gene and analysis of tolerance to water- and salt-stress in transgenic rice // Plant Sci--1998.-139, N 1.-P. 41-48.

67. Bhatnagar-Mathur P., Vadez V., Devi M. J., Lavanya M., Vani G., Sharma K. K. Genetic engineering of chickpea (Cicer arietinum L.) with the P5CSF129A gene for osmoregulation with implications on drought tolerance // Mol. Breed.-2009.-23, N 4.P. 591-606.

68. van Altvorst A. C., Bino R. J., van Dijk A. J., Lamers A. M. J., Lindhout W. H., van der Mark F., Dons J. J. M. Effects of the introduction of Agrobacterium rhizogenes rol genes on tomato plant and flower development // Plant Sci.-1992.-83, N 1.-P. 77-85.

69. Shen Q., Jiang M., Li H., Che L. L., Yang Z. M. Expression of a Brassica napus heme oxygenase confers plant tolerance to mercury toxicity // Plant Cell Environ.-2011.-34, N 5.-P. 752-763.

70. Liu H., Wang Q., Yu M., Zhang Y., Wu Y., Zhang H. Transgenic salt-tolerant sugar beet (Beta vulgaris L.) constitutively expressing an Arabidopsis thaliana vacuolar $\mathrm{Na}^{+} / \mathrm{H}^{+}$antiporter gene, AtNHX3, accumulates more soluble sugar but less salt in storage roots // Plant Cell Environ.-2008.-31, N 9.-P.1325-1334.

Received 17.06.13 